\title{
IDENTIFIKASI DAN STRATEGI PENURUNAN PENGANGGURAN DI KOTA PEKALONGAN
}

\author{
Beny Diah Madusari $^{1}$, Sobrotul Imtihanah ${ }^{2}$, Suryo Pratikwo ${ }^{3}$, Kuat Ismanto ${ }^{4}$ \\ ${ }^{1}$ Universitas Pekalongan \\ ${ }^{2}$ Universitas Muhammadiyah Pekajangan Pekalongan \\ ${ }^{3}$ Prodi Keperawatan Pekalongan, Poltekkes Kemenkes Semarang \\ ${ }^{4}$ Institut Agama Islam Negeri Pekalongan \\ 1,2,3,4 Dewan Riset Daerah Kota Pekalongan
}

\begin{abstract}
This study aimed to map and formulate a policy about unemployment in Pekalongan City, focusing on three things; the reasons of unemployment cause, people's interest of desired work, and an unemployment reducing policy. As a research method, we carried out a qualitative descriptive and used an open questions-questionnaire as the media for a hundred respondents, spread in 4 districts; Pekalongan Utara, Selatan, Barat, and Timur (Northern, Southern, Western, and Eastern Pekalongan). And in completing the study result, we also held a Focus Group Discussion (FGD) by inviting the budgeting-interested stakeholders. The results indicated three points; (1) a type of unemployment in Pekalongan is a frictional one; a condition where the jobless workers want to earn better wages, (2) a big interest of people to be an entrepreneur based on the big income and more time. And also, they hope the local government will support them in term of their capital easily and cheaply, and (3) from FGD, it resulted a suggestion to initiate 'a creative house' a media to accommodate the workshops outputs, and to formulate a regulation which obligate every business in Pekalongan to involve the local workers.
\end{abstract}

Keywords: Pekalongan, unemployment reduce, unemployment causes

\section{PENDAHULUAN}

Pengangguran adalah persoalan krusial bagi sebuah negara, begitu juga bagi sebuah provinsi, dan juga pemerintah kota/kabupaten. Ada dua dampak buruk pengangguran terhadap negara, yaitu: Pertama, dampak terhadap perekonomian Negara bersangkutan. Jika tingkat pengangguran di suatu negara relatif tinggi, hal tersebut akan menghambat pencapaian tujuan pembangunan ekonomi yang telah dicita-citakan. Kedua, dampak pengangguran terhadap individu yang mengalaminya dan masyarakat. Pengangguran dapat menghilangkan mata pencaharian, pengangguran dapat menghilangkan keterampilan, dan akan menimbulkan ketidakstabilan sosial politik (Muhdar, 2015).

Secara terminologi, pengangguran adalah istilah untuk orang yang tidak bekerja sama sekali, sedang mencari kerja, bekerja kurang dari dua hari selama seminggu, atau seseorang yang sedang berusaha mendapatkan pekerjaan yang layak (Mankiw, Quah, \& Wilson, 2006).
Menurut Sadono Sukirno (1994), pengangguran adalah suatu keadaan di mana seseorang yang tergolong dalam angkatan kerja ingin mendapatkan pekerjaan tetapi belum dapat memperolehnya. Berdasarkan pengertian pengangguran di atas, maka pengangguran dibagi menjadi tiga macam, yaitu: pertama pengangguran terbuka (open unemployment). Pengangguran terbuka adalah angkatan kerja yang sama sekali tidak mempunyai pekerjaan. Kedua, pengangguran terselubung (disguised unemployment). Pengangguran terselubung adalah pengangguran yang terjadi karena terlalu banyaknya tenaga kerja untuk satu jenis pekerjaan tertentu. Ketiga, setengah menganggur (under unemployment), yaitu bentuk pengangguran yang terjadi karena tenaga kerja tidak bekerja secara optimal karena tidak ada pekerjaan untuk sementara waktu (Prihanto, 2012).

Badan Pusat Statistik (2019) menjelaskan bahwa pengangguran terbuka adalah (a) 
Mereka yang tak punya pekerjaan dan mencari pekerjaan. (b) Mereka yang tak punya pekerjaan dan mempersiapkan usaha. (c) Mereka yang tak punya pekerjaan dan tidak mencari pekerjaan, karena merasa tidak mungkin mendapatkan pekerjaan. (d) Mereka yang sudah punya pekerjaan, tetapi belum mulai bekerja.

Ada beberapa sebab terjadinya pengangguran di Indonesia, di antaranya (a) ketidakseimbangan antara pekerjaan dan jumlah tenaga kerja. (b) kemajuan teknologi. (c) kemampuan para pencari kerja yang tidak sesuai. (d) kurangnya pendidikan dan keterampilan. (e) tingkat kemiskinan. (f) adanya PHK. (g) tempat tinggal yang jauh. (g) pasar global. (h) kesulitan bertemu pencari kerja dan lowongan pekerjaan (Franita, 2016).

Kajian tentang strategi pengangguran telah dilaksanakan oleh beberapa peneliti terdahulu. Studi-studi tentang pengangguran selalu diawali dari sebab-sebab terjadinya pengangguran. Contoh studi ini di antaranya dilakukan oleh Astuti, Ratnasari, \& Wibowo (2017) yang menunjukkan bahwa pengangguran terbuka salah satunya dipengaruhi oleh aktivitas yang ada di ASEAN Community. Luh, dkk. (2015) menemukan bahwa tingkat pengangguran secara tidak langsung dipengaruhi oleh pendapatan asli daerah dan dana perimbangan melalui belanja tidak langsung pada kabupaten/kota. Senada dengan hasil riset sebelumnya, bahwa kebijakan pemerintah terkait ketenagakerjaan juga akan berpengaruh terhadap tingkat pengangguran, khususnya di era otonomi daerah (Lisna, 2007). Namun di sisi lain, Nugroho (2016) menyampaikan bahwa tingkat pengangguran tidak dipengaruhi oleh besarnya upah yang diterima pekerja. Beberapa kajian tentang penyebab pengangguran di mancanegara dilakukan oleh Peter Norlander et al. (Norlander, Ho, Shih, Walters, \& Pittinsky, 2020) dan Nusair (2020).

Ada pun terkait dengan strategi yang ditempuh untuk mengurangi pengangguran, Sumardiningsih (2004) merekomendasikan beberapa hal, di antaranya memperluas kesempatan kerja di sektor informal, sektor agro, serta meningkatkan kesehatan masyarakat. Rekomendasi serupa juga disampaikan oleh Baeti (2013), bahwa pemerintah perlu berupaya untuk mengurangi jumlah pengangguran dengan cara meningkatkan pertumbuhan ekonomi dan meningkatkan alokasi pengeluaran pemerintah khususnya sektor pendidikan dan kesehatan untuk meningkatkan kualitas pembangunan manusia.

Berkaitan dengan persoalan pengangguran ini, Kota Pekalongan juga menghadapinya. Menurut Pemerintah Kota Pekalongan, pengangguran yang terjadi disebabkan oleh beberapa faktor, seperti bencana banjir rob dan terbakarnya Pasar Banjarsari. Data terakhir dari BPS Kota Pekalongan, angka pengangguran mencapai 5,05 persen atau sebanyak 301.870 jiwa pada tahun 2018 dibandingkan dengan jumlah angkatan kerja (Tribunnews, 2016). Meski demikian, tahun 2019 ini telah mengalami penurunan, meskipun angkanya belum signifikan (FGD, 2019). Kondisi ini menuntut Pemerintah Kota Pekalongan untuk mengambil sejumlah langkah untuk menguranginya, agar persoalan ini tidak berdampak pada sektor lainnya. Menurut Bambang Brojonegoro, (Kompas.com, 2019) dalam rangka mengurangi tingkat pengangguran, pemerintah pusat meningkatkan pendidikan dan pelatihan vokasi. Pemerintah juga akan memberi prioritas utama dalam Rencana Anggaran Belanja Negara (RAPBN) tahun 2019. Di samping itu, pemerintah juga mendorong program pendidikan dan pelatihan berbasis kompetensi untuk lebih dari satu juta orang. Persoalan ini tidak hanya menjadi tanggung jawab pemerintah daerah semata, tetapi juga pemerintah pusat, untuk itu diperlukan sinergitas pusat dan daerah. Berdasar uraian di atas, maka penelitian ini difokuskan pada upaya identifikasi pengangguran di Kota Pekalongan. Setelah itu, peneliti berupaya untuk menyususn strategi untuk memecahkannya.

Ada tiga tujuan utama yang ingin dicapai dari penelitian ini. a) Mengidentifikasi penyebab pengangguran di Kota Pekalongan. b) Mengetahui minat masyarakat terhadap jenis pekerjaan yang diinginkan. c) 
Menemukan strategi pemecahan masalah pengangguran yang terjadi di Kota Pekalongan. Dari kajian ini diperoleh manfaat bagi Pmerintah Kota Pekalongan, maupun pihak lainnya yang memiliki kepentingan terhadap hasil penelitian ini. Secara khusus manfaat yang diperoleh dari penelitian ini adalah: a) Memperoleh data deskriptif tentang penyebab pengangguran di Kota Pekalongan. b) Memperoleh data minat terhadap pekerjaan. Data ini berupa peminatan atas pekerjaanpekerjaan baru maupun lama. c) Memperoleh strategi untuk mengatasi permasalahan pengangguran di Kota Pekalongan.

\section{METODE PENELITIAN}

Penelitian ini dilaksanakan di Kota Pekalongan Provinsi Jawa Tengah. Ada beberapa alasan mengapa riset ini dilakukan di kota ini, pertama, Kota Pekalongan termasuk kota yang dilalui pengembangan jalan tol Trans Jawa. Kedua, Kota Pekalongan beberapa kali terkena banjir rob. Ketiga, kemajuan teknologi informasi menjadi bagian yang berdampak pada perkembangan pembangunan kota. Keempat, kota ini telah diakui oleh UNESCO sebagai kota kreatif dunia. Kelima, secara geografis Kota Pekalongan berada pada wilayah yang strategis.

Penelitian ini dikategorikan sebagai penelitian lapangan (field research) yaitu "suatu penelitian yang dilakukan secara sistematis dengan mengangkat data yang ada di lapangan" (Arikunto, 1992). Penelitian lapangan merupakan salah satu metode pengumpulan data dalam penelitian kualitatif yang tidak memerlukan pengetahuan mendalam akan literatur yang digunakan dan kemampuan tertentu dari pihak peneliti (Neuman, 2006). Secara operasional, peneliti berusaha untuk memahami fenomenafenomena pengangguran yang terjadi di Kota Pekalongan (Baeti, 2003).

Persoalan pengangguran di Kota Pekalongan dikaji dengan pendekatan deskriptif-kualitatif. Pendekatan kualitatif merupakan cara pandang peneliti dengan mengadopsi desain kualitatif dalam melakukan studi. Pendekatan ini dipilih karena memiliki beberapa karakteristik yang sesuai dengan riset ini, yaitu lebih bersifat umum, fleksibel, dinamis, eksploratif, dan bisa mengalami perkembangan selama proses penelitian berlangsung. Ada pun cara penyimpulan dilakukan secara induktif.

Populasi penelitian ini adalah masyarakat Kota Pekalongan yang berusia produktif. Yang dimaksud usia produktif adalah penduduk usia kerja yang sudah bisa menghasilkan barang dan jasa, yaitu berusia 15-54 tahun. Adapun sampel ditentukan dengan metode pengambilan sampel bertujuan (purposive sampling) (Sugiyono, 2011). Kriteria masyarakat yang dijadikan sampel memiliki syarat berusia produktif, baik yang sudah pernah bekerja maupun belum bekerja. Adapun responden ditemukan secara tidak sengaja atau disebut accidental sampling. Menurut Sugiyono (2011) accidental sampling adalah teknik penentuan sampel berdasarkan kebetulan, yaitu responden yang secara kebetulan/insidental bertemu dengan peneliti dan berkenan menjadi responden, bila dipandang orang yang kebetulan ditemui itu cocok sebagai sumber data.

Data primer penelitian dikumpulkan melalui kuesioner dan wawancara. Ada 100 responden yang dijadikan sampel dalam penelitian ini yang diambil dari empat kecamatan di Kota Pekalongan, yaitu Kecamatan Pekalongan Barat, Pekalongan Selatan, Pekalongan Timur, dan Pekalongan Utara. Metode analisis data yang dipilih adalah deskriptif analitis. Adapun pengertian dari metode deskriptif analitis menurut Sugiyono (2011) adalah suatu metode yang berfungsi untuk mendeskripsikan atau memberi gambaran terhadap objek yang diteliti melalui data atau sampel yang telah terkumpul sebagaimana adanya tanpa melakukan analisis dan membuat kesimpulan yang berlaku untuk umum.

3. HASIL PENELITIAN DAN PEMBAHASAN 3.1. Pengalaman Kerja

Kuesioner sebanyak 100 didistribusikan di empat kecamatan, yaitu Kecamatan Pekalongan Barat, Pekalongan Timur, Pekalongan Selatan, dan Pekalongan Utara. Responden yang pernah bekerja sebanyak 86 responden dan yang belum pernah bekerja 
sebanyak 16 orang. Jadi data yang digunakan dalam penelitian ini sebanyak 84 responden.

Tabel 1 Pengalaman Kerja

\begin{tabular}{cc}
\hline \multicolumn{1}{c}{ Aspek } & Jumlah \\
\hline Pernah Bekerja & 84 \\
Belum/Tidak Bekerja & 16 \\
Total & $\mathbf{1 0 0}$ \\
\hline Sumber: Data diolah 2019
\end{tabular}

Jawaban tentang pengalaman kerja ini sepenuhnya menjadi kebebasan responden untuk mendefinisikannya sendiri. Ada tiga alasan utama yang terungkap mengapa tidak tidak bekerja, di antaranya: tidak diizinkan oleh orang tua, diminta membantu usaha orang tua, dan alasan menikah.

\subsection{Profil Responden yang Pernah Bekerja}

Dari hasil penyebaran kuesioner di lapangan diperoleh data kategorisasi responden yang pernah bekerja. Responden laki-laki sebanyak 32 dan responden perempuan sebanyak 52, sebagaimana tampak pada tabel 2.

Tabel 2. Jenis Kelamin Responden

\begin{tabular}{cc}
\hline Jenis Kelamin & Jumlah \\
\hline Laki-Laki & 32 \\
Perempuan & 52 \\
Total & $\mathbf{8 4}$ \\
\hline
\end{tabular}

Sumber: Data diolah 2019

\subsection{Usia Responden yang Pernah Bekerja}

Responden penelitian ini adalah masyarakat yang berusia produktif, 15-64 tahun. Untuk mempermudah maka dilakukan kategorisasi menjadi 4 golongan. Usia reponden mayoritas usia muda, yaitu usia 1525 tahun yang berarti $50 \%$ lebih, sebagaimana tampak pada tabel 3. Data lebih mencerminkan harapan masyarakat Pekalongan karena mayoritas responden adalah usia muda.

Tabel 3. Usia Responden

\begin{tabular}{cc}
\hline $\begin{array}{c}\text { Usia } \\
\text { Responden }\end{array}$ & $\begin{array}{c}\text { Jumlah } \\
\text { Responden }\end{array}$ \\
\hline $15-25$ tahun & 51 \\
26-35 tahun & 15 \\
36-45 tahun & 8 \\
46-ke atas & 10 \\
Total & $\mathbf{8 4}$ \\
\hline Sumber: Data diolah 2019
\end{tabular}

\subsection{Tingkat Pendidikan Responden yang Pernah Bekerja}

Tingkat pendidikan responden pada penelitian ini paling tinggi adalah sarjana, namun jumlahnya sedikit. Jumlah paling banyak adalah berpendidikan SMA dan sederajat sebanyak 35 orang, diikuti SMP dan sederajat sebanyak 23 orang, dan SD dan sederajat sebanyak 18 responden.

Tabel 4. Pendidikan Responden yang Pernah

\begin{tabular}{cc}
\multicolumn{2}{c}{ Bekerja } \\
$\begin{array}{c}\text { Tingkat } \\
\text { Pendidikan }\end{array}$ & $\begin{array}{c}\text { Jumlah } \\
\text { Responden }\end{array}$ \\
\hline SD \& Sederajat & 18 \\
SMP \& Sederajat & 23 \\
SMA \& Sederajat & 35 \\
D2/D3/S1 & 7 \\
Lainnya & 1 \\
$\quad$ Total & $\mathbf{8 4}$ \\
\hline \multicolumn{2}{c}{ Sumber: Data diolah 2019 }
\end{tabular}

Riset ini belum mampu menggambarkan responden yang berpendidikan tinggi, seperti lulusan Perguruan Tinggi. Pendidikan SMA yang paling banyak, disusul SMP, dan SD.

\subsection{Pengalaman Kerja Pekerja di Kota Pekalongan}

Dari data yang diperoleh dari lapangan ditemukan bahwa pekerja sebagai buruh serabutan yang paling banyak ditemukan, yaitu 58 responden. Buruh pabrik sebanyak 22 responden dan pegawai swasta sebanyak 19 responden. Maksud buruh serabutan dalam penelitian ini adalah pekerja yang memperoleh upah kerja yang tidak didasarkan pada Upah Minimum Kota (UMK). Ada pun buruh pabrik adalah mereka yang memperoleh upah berdasar pada upah yang ditetapkan oleh pemerintah kota. Sedangkan yang dimaksud pegawai swasta adalah mereka yang bekerja di sebuah instansi yang upahnya telah merujuk pada UMR/UMK, seperti kerja di bank atau koperasi. Pengalaman kerja pekerja, divisualisasikan dalam diagram berikut. 


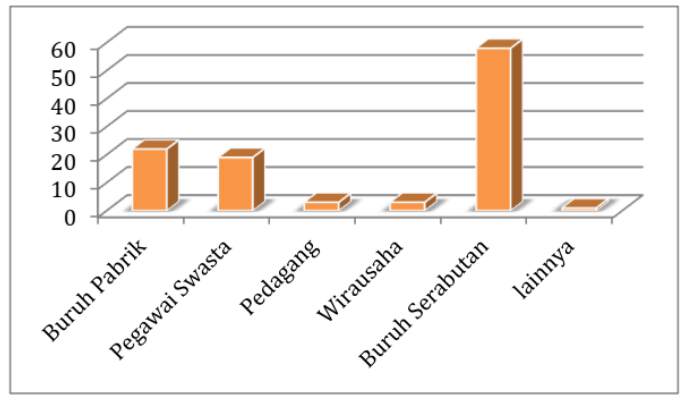

Diagram 1. Pengalaman Kerja Responden

\section{a) Alasan Berhenti Bekerja}

Selanjutnya peneliti mencari alasan-alasan atau penyebab responden berhenti bekerja. Dari berbagai alasan yang dikemukakan oleh responden, kemudian dibuat kategorisasi dengan cara mencari alasan yang serupa. Lima kategorisasi meliputi upah kurang, habis kontrak atau juga karena PHK, alasan individu, iklim kerja, dan juga alasan-alasan lainnya yang minoritas.

Persoalan atau alasan berhenti bekerja lebih disebabkan oleh alasan-alasan individu. Di antara contoh alasan individu adalah tidak ingin bergantung pada orang lain, ingin membuka usaha sendiri, bukan minat atau passion, dan alasan lainnya. Alasan berhenti bekerja dapat digambarkan dalam diagram berikut.

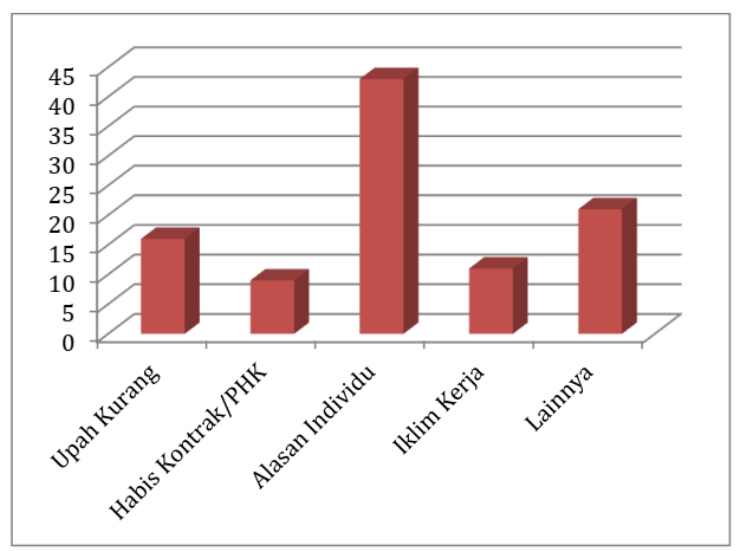

Diagram 2. Alasan Berhenti Kerja

\subsection{Minat Kerja Penduduk di Kota Pekalongan}

Di sub bab ini disajikan data pekerjaan yang diminati, alasan-alasan terhadap pekerjaan yang diminati serta harapan responden terhadap pemerintah kota Pekalongan. Responden yang digunakan dalam data ini adalah 100 .

\section{a) Pekerjaan yang diminati}

Dari responden sebanyak 100 orang, 45 orang ingin menjadi wirausaha. Keinginan ini merata di semua kecamatan. Minat pekerjaan sebagai pedagang dan buruh memiliki angka yang sama, yaitu 25. Minat menjadi wirausaha ini masih didominasi oleh bidang bisnis batik, dari aspek produksi maupun pemasaran. Visualisasi atas peminatan kerja ini digambarkan dalam diagram 3 berikut ini.

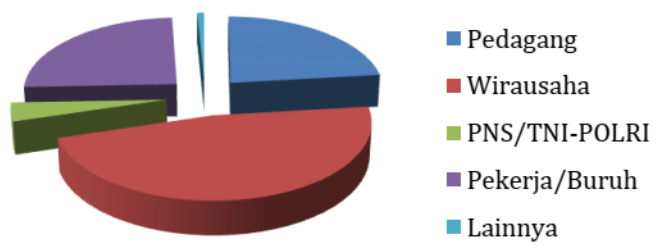

Diagram 3. Pekerjaan yang Diminati

b) Alasan Menjadi Pedagang/Wirausaha

Pekerjaan yang paling diminati adalah wirausahawan. Dari data kemudian ditelusuri alasannya, yaitu tidak terikat waktu, kemudian hasil besar, selanjutnya minat (passion), dan yang terakhir adalah sesuai pendidikan.

Ada juga responden yang menyampaikan bahwa dengan menjadi pengusaha waktu lebih mudah diatur. Wirausaha lebih mudah dikerjakan. Motivasi menjadi pedagang digambarkan dalam diagram berikut.

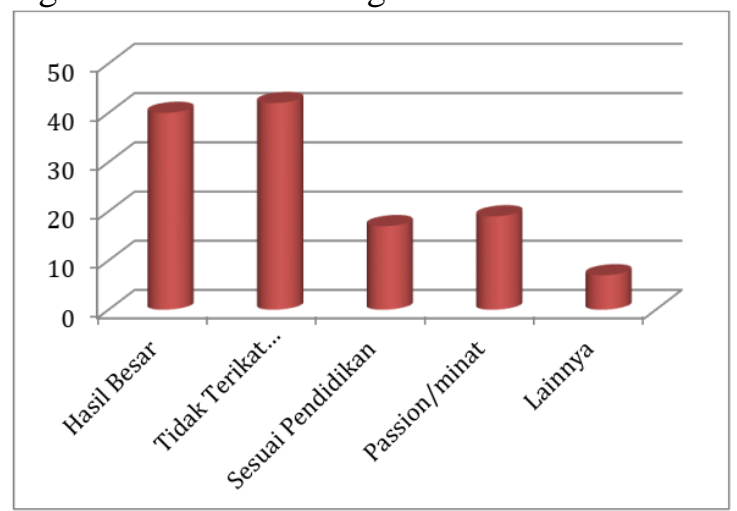

Diagram 4. Motivasi Menjadi Wirausaha

\section{c) Harapan masyarakat terhadap Pemerintah Kota Pekalongan}

Pada pertanyaan tentang harapan masyarakat terhadap pemerintah tentang pekerjaan, jumlah responden kembali menjadi 
100 orang. 16 orang yang belum/tidak bekerja dimasukkan ke dalam data ini.

Harapan yang banyak diharapkan oleh responden adalah agar pemerintah memperbanyak lowongan kerja sebanyak 44 responden. Adapun pinjaman modal diharapkan oleh 27 responden. Data harapan masyarakat digambarkan dalam diagram.

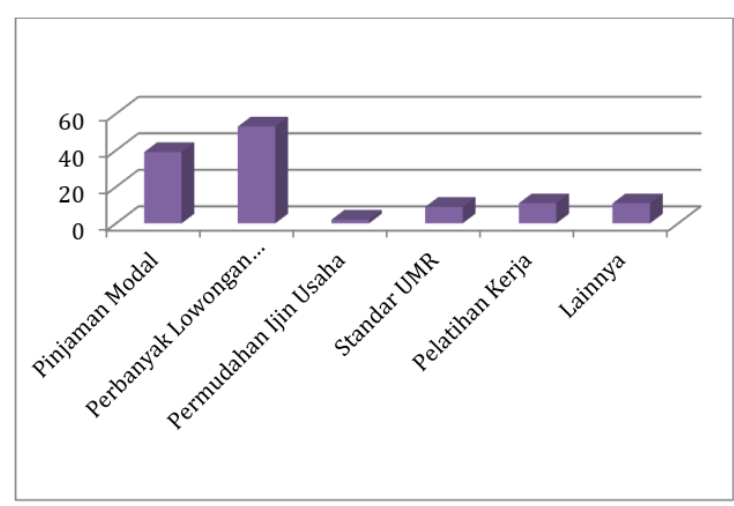

Diagram 5. Harapan Kerja

\section{d) Strategi Pengurangan Pengangguran di Kota Pekalongan}

Berdasar pada uraian di atas, ada beberapa catatan, serta solusi teoritis, dan juga strategi yang bisa diambil untuk mengurangi pengangguran. Di antara catatan itu adalah. 1) Dari yang semula bekerja sebagai buruh, pegawai swasta, dan juga lainnya mereka bercita-cita menjadi pedagang, wirausahawan atau memiliki usaha sendiri. Tidak banyak yang ingin menjadi TNI-Polri/PNS. 2) Alasan: tidak terikat waktu, hasilnya lebih menjanjikan, menciptakan lapangan kerja, sesuai ilmu yang dipelajari, bela negara, lebih mudah. 3) Deskripsi di atas menunjukkan bahwa tipe pengangguran di Pekalongan adalah friksional, yang berarti menganggur karena ingin mencari pekerjaan (hasil) yang lebih baik.

Berdasar pada catatan-catatan di atas, maka dirumuskan solusi teoritis berikut: 1) Perluasan kesempatan kerja dengan cara mendirikan industri-industri baru, terutama yang bersifat padat karya. 2) Deregulasi dan debirokratisasi di berbagai bidang industri untuk merangsang timbulnya investasi baru. 3) Menggalakkan pengembangan sektor informal, seperti home industry. 4) Menggalakkan program transmigrasi untuk menyerap tenaga kerja di sektor agraris dan sektor formal lainnya. Pembukaan proyek-proyek umum atau juga padat karya seperti pembangunan infrastruktur, jembatan, jalan raya, bangunan pemerintah, dan lain-lain sehingga bisa menyerap tenaga kerja secara langsung.

Strategi yang bisa dilakukan guna mengurangi pengangguran di Kota Pekalongan, di antaranya: 1) Memfasilitasi pembiayaan murah bagi pedagang/ wirausahawan bagi usaha yang unbankable. 2) Memberi pelatihan kewirausahaan berbasis IT bagi pedagang/wirausahawan. 3) Memfasilitasi perizinan usaha bagi pedagang/wirausahawan dengan mudah dan murah, melalui Online Single Submission(OSS).

e) Hasil Focus Group Discussion (FGD)

Guna melengkapi hasil penelitian ini, peneliti melakukan Focus Group Discussion (FGD) dengan mengundang berbagai instansi yang berkaitan dengan persoalan pengangguran yang diselenggarakan di gedung BKD Kota Pekalongan tanggal 12 Desember 2019. Di antara lembaga yang telah diundang adalah Anggota DRD Kota Pekalongan, Bappeda, Dinas Perindustrian dan Tenaga Kerja, Bagian Perekonomian Setda, Dinas Penanaaman Modal dan Pelayanan Terpadu Satu Pintu, Dinas Pendidikan, Dindagkop dan UKM, UPTD, BLK, SPSI, Serikat Pekerja.

Berdasar identifikasi lapangan, deskripsi data, dan strategi penelitian yang dilakukan, maka strategi pengurangan pengangguran di Kota Pekalongan yang bisa dilakukan antaranya:

1) Pelatihan bagi masyarakat di Balai Latihan Kerja (BLK) Kota Pekalongan tetap diteruskan dengan penguatan terhadap peserta melalui pakta integritas kesediaan mengikuti magang sampai tuntas.

2) Perlunya rumah industri atas produk eks peserta pelatihan BLK, dibentuk Rumah Kreatif di masing-masing kecamatan.

3) Fasilitasi Hak Kekayaan Intelektual (HaKI) atas produk Usaha Mikro Kecil dan Menengah (UMKM) di Kota Pekalongan. 
4) Membentuk jaring pengaman dengan pemantauan terhadap tenaga kerja pada perusahaan hotel, resto, dan lainnya atas warga Kota Pekalongan. Pemerintah Kota Pekalongan membuat regulasi untuk penyerapan tenaga kerja lokal dan bagi investor.

5) Pemerintah Kota Pekalongan menjalin kerja sama dengan daerah lain dalam pengembangan investasi.

6) Diperlukan tambahan data dari Dinas Kependudukan dan Catatan Sipil (Disdukcapil) guna pemetaan pengangguran.

7) Penggunaan upah buruh dengan standar KHL (Kebutuhan Hidup Layak).

8) Dinas Pendidikan telah melaksanakan ekstrakurikuler terkait pendidikan karakter dan Muatan Lokal (Mulok) dan telah mengratiskan pendidikan dasar.

\section{f) Pembahasan}

Pengangguran merupakan persoalan yang harus diselesaikan bagi pemerintah. Dari hasil riset diperoleh deskripsi bahwa tipe pengangguran yang ada di Pekalongan adalah pengangguran friksional. Oleh karena itu, solusi bisa diselesaikan dengan berbagai cara yang paling sederhana dan kongkrit. Hasil penelitian Ayati \& Purwanti (2018) mendukung pengangguran friksional yang dipengaruhi secara signifikan oleh antara jumlah tenaga kerja, tingkat pendidikan, saluran pencarian, dan jenis lowongan.

Salah satu harapan yang disampaikan oleh stakeholder, adalah mendatangkan investasi ke Pekalongan sebagai strategi untuk mengurangi tingkat pengangguran. Hasil penelitian Satrio (2010) menunjukkan bahwa investasi yang meningkat akan meningkatkan permintaan tenaga kerja sehingga tingkat pengangguran menurun. Untuk mengetahui dampak investasi langsung terhadap permintaan tenaga kerja digunakan koefisien tenaga kerja dan pengganda output untuk dapat mengetahui multiplier permintaan tenaga kerja.

Sekecil apa pun tingkat pengangguran di Pekalongan, maka harus segera diselesaikan secepatnya. Meskipun tahun 2019 ini mengalami penurunan dibanding dengan tahun-tahun sebelumnya yang mencapai angka
6\%. Sebab, menurut United Nations, transisi demografi yang terjadi pada beberapa dekade terakhir di Indonesia akan membuka peluang bagi Indonesia untuk menikmati bonus demografi (demographic devident) pada periode tahun 2020-2030 (Maryati, 2015).

\section{PENUTUP}

\subsection{Simpulan}

Dari uraian penyajian data dan pembahasan hasil penelitian di atas, setidaknya ada beberapa hal yang bisa diambil simpulan: (1) Tipe pengangguran yang ada di Pekalongan termasuk pengangguran friksional, yaitu satu bentuk pengangguran yang disebabkan oleh satu kondisi di mana pekerja ingin memperoleh pekerjaan lain dengan hasil yang lebih baik. Jenis pekerjaan baru yang paling diinginkan adalah menjadi wirausaha. (2) Responden memiliki harapan yang besar untuk menjadi wirausaha dengan dua alasan penting, yaitu harapan hasil yang besar dan kebebasan waktu. Hanya saja, mereka berharap bahwa ada bantuan pemerintah atas modal yang mudah dan murah. (3) Strategi yang bisa ditempuh oleh pemerintah Kota Pekalongan untuk mengurangi pengangguran adalah memperbanyak lapangan kerja, memfasilitasi bagi mereka yang ingin mengembangkan usaha, baik perizinan maupun permodalan, menyelenggarakan pelatihan, khususnya yang berbasis IT. (4) Dari hasil FGD diperoleh saran untuk mengurangi pengangguran, di antaranya BLK membentuk "Rumah Kreatif" yang menampung hasil peserta pelatihan. Membuat regulasi yang mewajibkan setiap usaha yang dibangun di Kota Pekalongan untuk melibatkan pekerja lokal. Pemerintah Kota Pekalongan bekerja sama dengan pemerintah daerah lain di sekitar (eks Karesidenan Pekalongan) untuk penyerapan tenaga kerja.

\subsection{Saran}

Ada beberapa keterbatasan penelitian ini, sehingga perlu dilakukan penyempurnaan oleh para peneliti selanjutnya agar strategi pengangguran yang direkomendasikan menjadi lebih tepat sesuai dengan metode yang digunakan, di antaranya: (1) Jumlah responden yang terbatas, maka perlu menambah jumlah responden, sehingga keterwakilan responden manjadi representatif. Mayoritas responden 
yang berstatus lulusan SMP dan SMA, maka kiranya perlu mencari responden yang lulusan perguruan tinggi. (2) Melakukan riset lanjutan, terkait karakteristik tenaga kerja Kota Pekalongan, serta sejauhmana warga Kota Pekalongan bekerja di perusahaan seperti hotel, mall, dan lainnya.

\section{REFERENSI}

Badan Pusat Statistik. (n.d.). Retrieved August 13, 2020, from https://www.bps.go.id/subject/6/tenagakerja.html

Franita, R. (2016). Analisa pengangguran di indonesia. Nusantaral Jurnal IlmuPengetahuanSosial ), 1 .

Muhdar, M. (2015). Potret Ketenagakerjaan, Pengangguran, Dankemiskinandi Indonesia: Masalah Dan Solusi. AlBuhuts.

Norlander, P., Ho, G. C., Shih, M., Walters, D. J., \& Pittinsky, T. L. (2020). The Role of Psychological Stigmatization in Unemployment Discrimination. Basic and Applied Social Psychology, 42(1), 29-49.

https://doi.org/10.1080/01973533.2019.1 689363

Nusair, S. A. (2020). The asymmetric effects of oil price changes on unemployment: Evidence from Canada and the U.S. Journal of Economic Asymmetries, 21, e00153. https://doi.org/10.1016/j.jeca.2019.e0015 3

Prihanto, P. H. (2012). Tren Dan Determinan Pengangguran Terdidik Di Provinsi Jambi. Jurnal Paradigma Ekonomika.

Sukirno, S. (1994). Pengantar Teori Ekonomi Makro. Jakarta: Penerbit Raja Grafindo.

Badan Pusat Statistik. (n.d.). Retrieved August 13, 2020, from https://www.bps.go.id/subject/6/tenagakerja.html

Franita, R. (2016). Analisa pengangguran di indonesia. Nusantaral Jurnal IlmuPengetahuanSosial ), 1 .

Muhdar, M. (2015). Potret Ketenagakerjaan, Pengangguran, Dankemiskinandi
Indonesia: Masalah Dan Solusi. AlBuhuts.

Norlander, P., Ho, G. C., Shih, M., Walters, D. J., \& Pittinsky, T. L. (2020). The Role of Psychological Stigmatization in Unemployment Discrimination. Basic and Applied Social Psychology, 42(1), 29-49.

https://doi.org/10.1080/01973533.2019.1 689363

Nusair, S. A. (2020). The asymmetric effects of oil price changes on unemployment: Evidence from Canada and the U.S. Journal of Economic Asymmetries, 21, e00153.

https://doi.org/10.1016/j.jeca.2019.e0015 3

Prihanto, P. H. (2012). Tren Dan Determinan Pengangguran Terdidik Di Provinsi Jambi. Jurnal Paradigma Ekonomika.

Sukirno, S. (1994). Pengantar Teori Ekonomi Makro. Jakarta: Penerbit Raja Grafindo.

Arikunto, S. (1992).Prosedur Penelitian: Suatu Pendekatan Praktik. Jakarta: Rineka Cipta.

Astuti, W. I., Ratnasari, V., \& Wibowo, W. (2017).Analisis Faktor yang Berpengaruh Terhadap Tingkat Pengangguran Terbuka di Provinsi Jawa Timur Menggunakan Regresi Data Panel.Jurnal Sains Dan Seni ITS.https://doi.org/10.12962/j23373520.v 6 i1.22977.

Ayati, H. N., \& Purwanti, E. Y. (2018).Analisis Pengangguran Friksional Di Kabupaten Semarang (Doctoral dissertation, Fakultas Ekonomika dan Bisnis).

Baeti, N. (2013). Pengaruh Pengangguran, Pertumbuhan Ekonomi, dan Pengeluaran Pemerintah Terhadap Pembangunan Manusia Kabupaten/Kota di Provinsi Jawa Tengah Tahun 20072011. Economics Development Analysis Journal, 2(3).

Lisna, E. (2007). Dampak Kebijakan Ketenagakerjaan Terhadap Tingkat 
Pengangguran dan Perekonomian Indonesia di Era Otonomi Daerah.In Disertasi Institute Pertanian Bogor.

Luh, N., Adriani, G. C., Nyoman, I., \& Yasa, M. (2015). Pengaruh pendapatan asli daerah dan dana perimbangan terhadap tingkat pengangguran melalui belanja tidak langsung pada kabupaten/kota di provinsi Bali. E-JurnaNtEP\tUnud.

Mankiw, N. G., Quah, E., \& Wilson, P. (2006).Pengantar ekonomi makro. Jakarta: Salemba Empat.

Maryati, S. (2015). Dinamika pengangguran terdidik: tantangan menuju bonus demografi di Indonesia. Economica: Jurnal Program Studi Pendidikan Ekonomi STKIP PGRI Sumatera Barat, 3(2), 124-136.

Neuman, W. L., \& Neuman, L. W. (2006).Workbook for Neumann Social Research Methods: Qualitative And Quantitative Approaches. Allyn \& Bacon.

Nugroho, R. E. (2016). Analisis Faktor Faktor Yang Mempengaruhi Pengangguran di Indonesia Periode 1998 - 2014. Jurnal PASTI. https://doi.org/10.1177/088506660832697 $\underline{2}$.

Satrio, D. (2010). “Analisis Dampak Investasi Pada Industri Pulp dan Kertas Terhadap Kesempatan Kerja dan Pendapatan Rumah Tangga Indonesia”.Tesis. Program Pascasarjana Universitas Diponegoro.
Sugiyono. (2010). Metode Penelitian Kuantitatif, Kualitatif, dan $R \& D$. Bandung: CV Alfabeta.

Sukirno, S. (1994). Pengantar Teori Ekonomi Makro. Penerbit Raja Grafindo, Jakarta.

Sumardiningsih, S. (2004).Upaya Mengatasi Pengangguran di Kabupaten Kulon Progo. Jurnal Ekonomi dan Pendidikan, 1 (2).

\section{Berita Online}

"Ini Jurus Pemerintah agar Pengangguran Turun Pada 2019", https://ekonomi.kompas.com/read/2018/0 9/12/070600926/ini-jurus-pemerintahagar-pengangguran-turun-pada2019? page $=$ all. https://ekonomi.kompas.com/read/2018/0 9/12/070600926/ini-jurus-pemerintahagar-pengangguran-turun-pada2019? page $=$ all. Diakses 6 Desember 2019.

Angka Pengangguran di Kota Pekalongan Meningkat, Saat Ini Capai 6 Persen Lebih, https://jateng.tribunnews.com/2019/07/31/ angka-pengangguran-di-kota-pekalonganmeningkat-saat-ini-capai-6-persenlebih.Diakses 6 Desember 2019.

https://www.thebalance.com/types-ofunemployment-3305522 10 Oktober 2019. 